Western Washington University

Western CEDAR

9-2011

\title{
'If Shanxi's Coal is Lost, Then Shanxi is Lost!': Shanxi's Coal and an Emerging National Movement in Provincial China, 1898-1908
}

Roger R. Thompson

Western Washington University, roger.thompson@wwu.edu

Follow this and additional works at: https:// cedar.wwu.edu/history_facpubs

Part of the History Commons

\section{Recommended Citation}

Thompson, Roger R., "'If Shanxi's Coal is Lost, Then Shanxi is Lost!': Shanxi's Coal and an Emerging National Movement in Provincial China, 1898-1908" (2011). History Faculty and Staff Publications. 9.

https://cedar.wwu.edu/history_facpubs/9 


\title{
'If Shanxi's Coal is Lost, then Shanxi is Lost.': Shanxi's Coal and an Emerging National Movement in Provincial China, I 898- 1908
}

\author{
ROGER R. THOMPSON
}

\author{
Western Washington University, Department of History, 5 I 6 High Street, \\ Bellingham, Washington 98225-9061, USA \\ Email:Roger.Thompson@wwu.edu
}

\begin{abstract}
The land-locked north China province of Shanxi, identified in 1870 by the geologist Baron Richthofen as 'one of the most remarkable coal and iron regions in the world', was the site of a provincially-defined national movement far removed from the better-studied treaty ports and their articulate and prolific nationalists. This late-Qing provincialism may be read as a mediating symbol of an emerging national consciousness.

Social tensions were exacerbated by external challenges brought by foreign agents, and their Chinese collaborators, of cultural and economic imperialism. Opposition to missionaries and Chinese Christians had begun as early as the 186os. In 1898 the British Pekin Syndicate and its extra-provincial Chinese associates, with the backing of the central government, secured rights to Shanxi's rich coal and iron resources. These rights were ceded back ten years later after a successful 'rights-recovery' movement that possesses similarities to (but also significant differences from) the well-studied oppositional movements in Jiangsu, Zhejiang, Hunan, and Shandong in the period 1905-1911. The duration of Shanxi's struggle, along with its extra-bureaucratic elite activism, popular mobilization, and cooperation with Beijing, makes its rights-recovery movement distinctive. The rhetoric and practices of the movement, which began before the Boxer Uprising of 1900 and reflects the rhetorical influence of these earlier protests, contributed to a strong regional solidarity that was backed by central state authority. There were various patterns of protest, one indigenous and provincial, one extra-provincial and nationalist, that interacted in the period 1902-1908. Provincial activists, including merchants, peasants, students, degreeholders, and officials, insisted that Shanxi's coal was for the use of the community, the province, and the nation on terms established by and for the people of Shanxi. In their victory, localism, provincialism, and the national project, had come together.
\end{abstract}




\section{Introduction}

Writing from Beijing in June 1870 , the eminent and well-respected geologist and geographer Baron Richthofen informed the Western business community in Shanghai that the land-locked north China province of Shanxi, which he had just surveyed, 'is one of the most remarkable coal and iron regions in the world'. He went on to write 'that the world, at the present rate of consumption, could be supplied for thousands of years from Shansi [Shanxi] alone'. ${ }^{1}$ These initial findings were published in 1870 and reprinted in 1875 ; Richthofen's Shanxi report also appeared in compilations published in 1870 and 1872. ${ }^{2}$ By 1873 Parliament had discussed Shanxi's coal. ${ }^{3}$ A quarter

${ }^{1}$ Baron Ferdinand von Richthofen, Baron Richthofen's Letters, I $870-1872$ (Shanghai, 1872), p. 43. Richthofen's investigations in Shanxi and elsewhere were done on behalf of the Shanghai General Chamber of Commerce. Richthofen began his Shanxi survey in April 1870, beginning at the border between Shanxi and Henan at Zezhou Prefecture. Richthofen then travelled towards the Fen River at Pingyang, went upriver to the plain south of Taiyuan, and to the mountains east of Taiyuan by mid-May 1870. Richthofen published his detailed field notes in 1882. See Baron Ferdinand von Richthofen, China: Ergebnisse Eigener Reisen und darauf Gergründeter Studien (China: The Results of My Travels and the Studies Based thereon), Vol. 2, Das Nördliche China (North China) (Berlin: Verlag von Dietrich Reimer, 1882), pp. 399-453. In this 1882 volume Richthofen calculated that the coal in southern Shanxi alone could supply the world for 2,100 years. See Richthofen 1882, 439n 1.

${ }^{2}$ Richthofen's report on Shanxi, which also included notes on Henan, was published at least twice in 1870 . See Baron Ferdinand von Richthofen, Report by Baron von Richthofen on the Provinces of Honan and Shansi (Shanghai, 1870); Reports on the Provinces of Hunan, Hupeh, Honan, and Shansi (Shanghai, 1870). The report on Henan and Shanxi was reprinted in 1875 . See Baron Ferdinand von Richthofen, Report by Baron von Richthofen on the Provinces of Honan and Shansi (Shanghai, 1875).

${ }^{3} \mathrm{Hu}$ Zhonggui, ed., Shanxi meitan gongye jianshi (A brief history of Shanxi's coal industry) (Taiyuan: Shanxi kexue jiaoyu chubanshe, 1988), p. 35. England's increasing reliance on coal had transformed its economy in the previous three centuries and by the 1860 s several royal commissions had addressed the 'coal question'. Would there be adequate supplies for future economic growth? England's transition from an advanced organic economy in which all energy flows were solarbased to a mineral-based energy economy, originally based on coal, was a precondition for its industrial revolution. See E. A. Wrigley, Continuity, Chance and Change: The Character of the Industrial Revolution in England (Cambridge: Cambridge University Press, 1988). The British energy model was transforming the world. In the United States, for example, it was seized upon by William Palmer, who had studied Britain's collieries and coal-consuming industries in 1855 before he explored the Colorado Territory in America's West in the summer of 1867 . Palmer realized that importing the British model to Colorado was the key to the region's economic development. Like Shanxi, Colorado was a coal-rich, high-altitude, dry region without access to inexpensive water transport. Colorado's transformation from an organic-energy economy into a mineral-intensive economy began in the 1870 . See Thomas G. Andrews, Killing 
of a century later much of this critical energy resource, one of the most extensive coal reserves in the world, ${ }^{4}$ was claimed by the Pekin Syndicate. Founded in 1897 with Lord Rothschild as principal shareholder, the Pekin Syndicate, with the support of the British government, sought and gained mining rights to Shanxi's coal in May $1898 .^{5}$

In a vivid demonstration of its knowledge and power the West soon began its preparation to exploit this natural resource, and yet, within ten years, the people of Shanxi had used this same knowledge, even paraphrasing Richthofen or his popularizers like Lord Beresford and Brooks Adams, ${ }^{6}$ not as a tool for resource exploitation, but rather as

for Coal: America's Deadliest Labor War (Cambridge: Harvard University Press, 2008). The British model came to China in general, and Shanxi in particular, about the same time. See Tim Wright, Coal Mining in China's Economy and Society, I895-1937 (Cambridge: Cambridge University Press, 1984), p. 36. China, however, remained an advanced organic economy for decades to come, but by 1990 its coal production was the largest in the world. See Vaclav Smil, Energy in World History (Boulder, Colorado: Westview Press, 1994), p. 186. Richthofen's vision of extracting Shanxi's mineral wealth was finally realized, but the coal would stay in China, where a third of all coal consumed worldwide is being used in an increasingly mineral-based energy economy in the twenty-first century. See Massachusetts Institute of Technology, The Future of Coal: Options for a Carbon-Constrained World (Cambridge: Massachusetts Institute of Technology, 2007), pp. 63-64. For a popular account of the domestic realities, including a firsthand look at Shanxi, and the global implications of the post-1949 transformation of China's energy economy, see Barbara Freese, Coal: A Human History (Cambridge, Massachusetts: Perseus Publishing, 2003), pp. 199-231.

${ }^{4}$ George Babcock Cressey, China's Geographic Foundations: A Survey of the Land and Its People (New York: McGraw-Hill, 1934), p. 113. Cressey suggested that north China's coal reserves (along with America's Appalachian region and the lower Rhine River valley in Europe) were among the top three. More recent estimates put 8o per cent of the world's most extensive reserves in Russia, the United States and China. A 1930 geological survey of China's known reserves estimated that 5 o per cent were in Shanxi. See Smil, p. 218 ; Wright, p. 8o. Smil suggests that the 'world's coal resources could last for almost 5oo years at the 1990 rate of extraction.' See Smil, p. 218.

${ }^{5}$ E. W. Edwards, British Diplomacy and Finance in China, I895-I9I4 (Oxford: Clarendon Press, 1987), pp. 32-33; Hu Zhonggui, ed., Shanxi meitan gongye jianshi (A brief history of Shanxi's coal industry) (Taiyuan: Shanxi kexue jiaoyu chubanshe, 1988), p. 36; for a text of the agreement see John V. A. MacMurray, comp. and ed., Treaties and Agreements with and concerning China, I894-I9I9, vol. 1 (Manchu Period (1894-1911) (New York: Oxford University Press, 1921), pp. 700-702.

6 This knowledge about Shanxi became commonplace by the turn of the century. Lord Beresford, in his 1899 comments about the British Pekin Syndicate, reported that Shanxi coal and iron fields could well be the largest in the world. See Lord Charles William Beresford, The Break-up of China; with an account of its present commerce, currency, waterways, armies, railways, politics, and future prospects (New York: Harper, 1899), p. 313 . A few years later Brooks Adams, brother of Henry Adams and a friend of US Secretary of State, John Hay, mentioned Richthofen's assessment that southern Shanxi had the 
a potent political symbol to use against the West. Their power came not from financial institutions or military units but from the people.

Shanxi was the site of a provincially-defined national movement far removed from the better-studied treaty ports and their articulate and prolific nationalists. This late-Qing provincialism may be read as a mediating symbol of an emerging national consciousness; it is not an easy terrain to explore. As Eric Hobsbawm points out, there is a dense fog that surrounds questions about the national consciousness of men and women whose primary concerns are those of daily survival. ${ }^{7} \mathrm{My}$ evidence, while it does not allow access to the interior musings of peasants in Shanxi, does document action from which may be inferred a developing national consciousness. Elite actors, some of whom may be taken as spokesmen for larger community concerns, have left brief examples of rhetorical affirmations of community, province, and nation. These traces, however, may not fit into the dominant genre of nationalist discourse to which we have become accustomed when discussing the origins of Chinese nationalism. In particular, the race and language-oriented arguments for defining nations that were sweeping Europe in the late-nineteenth century and were dutifully interpreted by activists like Liang Qichao and Zhang Binglin are not to be found in Shanxi, but their absence alone should not be taken as evidence for the lack of a national consciousness among the people of Shanxi. ${ }^{8}$

A more instructive Western parallel comes from an earlier period in the nineteenth century when the 'national question' was discussed in economic terms. Alexander Hamilton, for example, stressed the

'richest beds of coal and iron now known to exist, and undeveloped, in the world'. See Brooks Adams, The New Empire (New York: Macmillan, 1903), p. 189. Adams went on to declare: 'The greatest prize of modern times is northern China' (p. 19o). For another precise reference to Richthofen's estimate see E. H. Edwards, Fire and Sword in Shansi: The Story of the Martyrdom of Foreigners and Chinese Christians (New York: Revell, 1903), p. 38. Edwards opens his book: 'Long before the eventful year 1900 the province of Shansi had attracted the attention of travellers, scientists, and capitalists by its abounding mineral wealth, first brought to the knowledge of the world by the explorations of Baron von Richthofen' (p. 33).

${ }^{7}$ E. J. Hobsbawm, Nations and Nationalism since I780: Program, Myth, Reality (Cambridge: Cambridge University Press, 1990), p. 79.

${ }^{8}$ For a similar argument, based on a study of Hunan intellectual history, see Stephen R. Platt, Provincial Patriots: The Hunanese and Modern China (Cambridge: Harvard University Press, 2007). For an overview of the extensive literature on nationalism in modern Chinese history see Zhao Suisheng, A Nation-State by Construction: Dynamics of Modern Chinese Nationalism. (Stanford, California: Stanford University Press, 2004). 
importance of the links between nation, state, and economy and argued for state protection of national economies. Friedrich List, one of the foremost proponents of what might be called economic nationalism, stressed the importance of a 'national economy' or a 'people's economy' as he argued against the free-trade tenets of political economists like Adam Smith. ${ }^{9}$

As Shanxi's economic fortunes declined and foreign influences increased a multi-class opposition to the concession granted in 1898 emerged. The rhetoric and practices of this movement demonstrate clearly how strong regional solidarity, especially when backed by central state authority, could combine for what might be called a nationalist triumph. Peasants, students, merchants, and degreeholders were participants and Shanxi bankers raised part of the capital needed to compensate the syndicate. Moreover, this particular rights-recovery movement, which possesses similarities to, but also significant differences from, the well-studied oppositional movements in Jiangsu, Zhejiang, Hunan, and Shandong in the period 19051911 , is evidence of understudied nuances of extra-bureaucratic elite activism and popular mobilization in late-Qing China.

The best-studied rights-recovery movement (shouhui liquan), which refers to both mining and railroad concessions, took place in the lower Yangzi region and was led by well-known and eminent gentrymen and merchants like Zhang Jian, Tang Shouqian, and Li Houyou. The movement in Zhejiang and Jiangsu dates to 1903, when Chinese students in Japan and Zhejiangese officials in Beijing protested against foreign influence and control of a planned railroad between Hangzhou and Suzhou. These protests became better-organized and publicized beginning in $1905 .{ }^{10}$

A similar protest in Guangdong, Hunan, and Hubei concerned the proposed railroad between Canton and Hankou. In this case the leaders of the movement were primarily provincial officials like Zhang Zhidong, rather than provincial elite. Railway rights were returned to the Chinese in 1905 after a payment, made possible by a foreign loan, was made by Zhang Zhidong; the loan was repaid from the provincial

${ }^{9}$ Hobsbawm, pp. 29-30.

${ }^{10}$ See Mary Backus Rankin, Elite Activism and Political Transformation in China: Zhejiang Province, I 865-I9I I (Stanford, California: Stanford University Press, 1986), pp. 263-296; Madeleine Chi, 'Shanghai-Hangchow-Ningpo Railway Loan: A Case Study of the Rights Recovery Movement', Modern Asian Studies 7 (1973): 85-106. 
treasuries of Hunan and Hubei. ${ }^{11}$ Unlike the movement in Jiangsu and Zhejiang, provincial elite participation was less central. These features can also be found in the mining-rights-recovery movement in Shandong. This movement, which sought to ensure Chinese access to most of the sixty-li zone in Shandong bisected by a planned Germanbuilt railroad as well as five large areas elsewhere, won the recognition that Chinese-owned mines, using modern technology if desired, could be operated in these zones. The price tag for Chinese access to the five large zones cost the province 340,000 taels and 210 ,ooo Chinese dollars. $^{12}$

Li Enhan categorized the various mining-rights movements as follows: (1) concessions in Zhejiang and Sichuan that were abrogated because terms in the original contract were not met; (2) voluntary renunciation of rights such as the German decision in Shandong's sixty-li zone between Qingdao and Ji'nan; and (3) the type of movement found in Shanxi, Anhui, Hunan, and other German areas in Shandong that ended after a negotiated redemption fee was paid by the Chinese. ${ }^{13}$

The Shanxi rights-recovery movement shared with these various movements the nationalistic rhetoric characteristic of the period $1905^{-1911}$, the cooperation of provincial officials, gentry, merchants, new-style students, and fellow provincials in Beijing, and an emphasis on blocking close foreign involvement in railway and mining projects. But there were also important differences: (1) a lineage to protests taking place during and before 1900; (2) mobilization that included active participation of non-elite elements; and (3) relative unanimity within the provincial elite, including both gentrymen and the merchant elite. Li Enhan's treatment of the Shanxi movement stresses the similarities (although he glances over the gentry and student mobilization), but does not explore the differences just noted. ${ }^{14}$

${ }^{11}$ Daniel H. Bays, China Enters the Twentieth Century: Chang Chih-tung and the Issues of a New Age, I895-1909 (Ann Arbor, Michigan: University of Michigan Press, 1978), pp. $163-184$.

12 See John E. Schrecker, Imperialism and Chinese Nationalism: Germany in Shantung (Cambridge, Massachusetts: Harvard University Press, 1971), 179-191; En-han, Lee [Li Enhan], 'China's Response to Foreign Investment in Her Mining Industry (1902-1911),'Journal of Asian Studies 28 (1968): 66.

13 Ibid., p. 73 .

${ }^{14}$ Li's 1963 book included a chapter on the pre-1905 period. See Li Enhan, WanQing de shouhui kuangquan yundong (The movement to recover mining rights in the late Qing) (Taibei: Zhongyang yanjiuyuan jindaishi yanjiusuo, 1963), pp. 201-221. 
The questions explored here-how and by whom Shanxi's vast coal reserves should be exploited-emerged in the context of an economic depression in 1890 Shanxi when the interconnection of its regional economy with national and international networks, once a strength, became a source of weakness. The province's high-quality iron products, its national network of bankers, and its role in transshipping and marketing goods to Mongolia and Russia from elsewhere in China, which had contributed to a flourishing economy in the mid-nineteenth century, were adversely affected as Shanxi's economy suffered a severe downturn. Among the contributing factors were the import of cheaper Western or Western-style goods that became increasingly available after 1842 in Shanxi, and the reorganization of national public finance at the turn of the century that affected the fortunes of Shanxi's bankers. $^{15}$

\section{Social Context}

Shanxi communities suffered a crisis of legitimacy which had been developing in social, cultural, and moral arenas in the years following the signing of the Treaty of Tianjin in $185^{8}$ and the Convention of Beijing in 1860, when Catholic and then Protestant missionaries began to use extraterritorial rights and new Chinese laws governing religious toleration to undermine the ritual life of Shanxi villagers. This crisis, endemic during the final decades of the nineteenth century, contributed to the explosion of violence in Shanxi in 190o, and was definitively resolved in the post-Boxer era in a way that served to estrange the rural elite, and the communities they led, from the state. ${ }^{16}$ Shanxi's urban-based bankers, however, grew in importance. The wealth and influence of merchant capital in Shanxi, particularly that of its network of bankers both within the province and throughout

${ }^{15}$ For an exploration of Shanxi's wealth and influence prior to the devastating famine of 1876-1879 see Kathryn Edgerton-Tarpley, Tears from Iron: Cultural Responses to Famine in Nineteenth-century China (Berkeley, California: University of California Press, 2008). Additional detail on events between 1840 and 1908 can be found in Shanxi dashiji (I840-1985) (A chronology of important events in Shanxi, 1840-1985), edited by Shanxi sheng difangzhi bianzuan weiyuanhui (Taiyuan: Shanxi renmin chubanshe, 1987), pp. 1-83.

${ }^{16}$ Roger R. Thompson, 'Twilight of the Gods in the Chinese Countryside: Christians, Confucians, and the Modernizing State, 1861-1911', in Christianity in China: From the Eighteenth Century to the Present, edited by Daniel H. Bays (Stanford, California: Stanford University Press, 1996), pp. 53-72. 
China, became quite significant in late-nineteenth century Shanxi, a development that caused alarm among the less commercially-inclined elite. As we will see, this wealth and the families represented were key elements in a provincialist defence of Shanxi's natural resources that brought together various strands of political activism in Shanxi.

This interconnection between the national and provincial can also be seen in the impact of the transformation of China's method of selecting its political elite. The abolition of the examination system in China, announced in 1905, had already been effectively accomplished in Shanxi's core regions by 1901 as a consequence of government actions, mandated by the victorious Allies, taken after the Boxer Uprising. ${ }^{17}$ The blocking of this avenue to wealth and power contributed to the quick development of new-style schools that were founded in the provincial capital beginning in 1902. Degree-holders from throughout the province became students at the indemnity-funded Shanxi University, a military academy and agricultural school. ${ }^{18}$ Alongside such students could be found those who would never have participated in the old-style examination system. The best students from both categories could be awarded government scholarships to continue their studies in Japan and England. ${ }^{19}$ In Shanxi, new opportunities for social mobility identified with new-style school matriculation became apparent three years in advance of nationwide implementation of new educational policies.

Shanxi was one of the first provinces (August 1902) to publish a new-style government gazette in the post-Boxer period. ${ }^{20}$ Henrietta Harrison's research highlights the ways in which news and rumours circulated in Shanxi and identifies the interaction of these familiar means of communication with the growth of new-style newspapers and government gazettes at the turn of the century. Even before the advent of new-style publications Shanxi's literate males, who could be found throughout China in a banking network, and in north China in

${ }^{17}$ Shanxi dashi ji, p. 70.

18 Shanxi dashi ji, pp. 73-74. For a discussion of the programmes and students at Shanxi University see William E. Soothill, Timothy Richard of China: Seer, statesman, missionary and the most disinterested adviser the Chinese ever had (London: Seeley, Service, 1924), pp. 253-270.

${ }^{19}$ In the autumn of 1904 Governor Zhang Zengyang sent $5^{0}$ students to Japan. See Shanxi dashi ji, p. 75. In the spring of 190725 graduates from Shanxi University were sent to England for a five-year course of study. See Shanxi dashi ji, p. 82; The Times, 3 June, 1907, p. 5; Soothill, p. 266.

${ }^{20}$ Shanxi dashiji, p. 74. 
'IF SHANXI'S GOAL IS LOST, THEN SHANXI IS LOST!' 1269 particular in a clerking network, kept the province informed of extraprovincial news through their letter-writing. Once in Shanxi this news could be spread further along informal networks of communication. ${ }^{21}$ Formal communication between government offices took place and official notices were posted on walls outside government compounds. Formally and informally, news and information from local, provincial, and national sources circulated in Shanxi. When increased literacy and schooling affected Shanxi, it enhanced social communication in an environment that could scarcely be called parochial.

However, there was social tension in Shanxi exacerbated by external challenges of cultural and economic imperialism brought by foreign agents and their Chinese collaborators. The spirited defense by some Shanxi natives of symbolic and economic resources was opposed by other Shanxi persons, and both sides had extra-provincial allies. These struggles had implications for Shanxi's relationship with central authority in China as well as for China's international relationships. By exploring the articulation of these conflicts, expressed in both national and provincial terms, we can trace the development of a fruitful approach to nation-building that is predicated on strong provincial, but not necessarily parochial, loyalties.

Let us turn, then, to the question of Shanxi's coal and who should control its exploitation.

\section{Shanxi and the Pekin Syndicate, 1898-1901}

As early as 1896 the Qing government encouraged iron mining in Shanxi and, by December 1896 , a commercial enterprise dedicated to coal and iron mining had been established. On 14 July, 1897, the Shanxi governor, Hu Pinzhi, memorialized a recommendation to first build a railroad into Shanxi in order to develop mining enterprises. ${ }^{22}$ Hu knew that Shanxi's rich coal resources could contribute to national development, so he was committed to importing Western mining techniques and extra-provincial capital resources in order to develop mines and to build the railroads to bring the coal to market. ${ }^{23}$ For

${ }^{21}$ Henrietta Harrison, 'Newspapers and Nationalism in Rural China, 1890-1929,' Past and Present 166 (2000): 1 81-204.

${ }^{22}$ Shanxi dashiji, pp. $5^{8-59}$.

${ }^{23}$ Mi Rucheng, ed., Zhongguo jindai tielu shi ziliao, I863-I9I I (Source materials on the history of railways in modern China, 1863-1911) (Beijing: Zhonghua shuju, 1963), vol. 2, p. 411 . 
these reasons Hu Pinzhi allowed two extra-provincials, Liu E and Fang Xiaojie, to form the Jinfeng Company (Jinfeng gongsi) for the purpose of borrowing money from foreign banks in order to develop mining in the central-east area in which Yu County and Pingding Department were located, and in the southeastern prefectures of Lu'an and Zezhou. ${ }^{24}$ Liu E, better known as author of The Travels of Lao Can (Laocan youji), had ties to Li Hongzhang's well-connected protégé, Ma Jianzhong. By the end of 1897 Liu E was negotiating an agreement between Shanxi officials associated with the province's Commercial Affairs Bureau (Shangwu ju) and the Pekin Syndicate. ${ }^{25}$

There was opposition almost immediately. On 28 February, 1898 a censor named Xu Shuming memorialized that Shanxi's mining and railroad rights should be returned to the gentry and people (shenmin) ${ }^{26}$ $\mathrm{Xu}$ was concerned about the strategic implications for a defence of Beijing presented by the prospect of a railroad in Shanxi and also thought that merchant-dominated exploitation of Shanxi's coal resources would be detrimental to the economic interests of Shanxi's gentry and people. Xu's was one of a half-dozen similar petitions and memorials submitted in early 1898 . Particular concern was expressed about the economic effect on small-scale mining operations in the areas being discussed for the concession. ${ }^{27}$

$\mathrm{Hu}$ Pinzhi was ordered to comment, ${ }^{28} \mathrm{Liu} \mathrm{E}$ and his associate were pushed aside by imperial edict, and the Commercial Affairs Bureau took over the Jinfeng Company. ${ }^{29}$ But the concession-hunting continued and on 17 May, 1898 imperial approval was given to a 20-article agreement that had been reached between the Shanxi Commercial Affairs Bureau and the Pekin Syndicate. The agreement was signed on 21 May. The syndicate was granted rights to mine in Lu'an Prefecture (Changzhi), Zezhou Prefecture (Jincheng), Pingding Department, Yu County, and also in Pingyang Prefecture (Linfen) in central Shanxi, in return for tax payments, profit-sharing, and a promise to turn the operations over to the Chinese after 6o years. ${ }^{30}$

${ }^{24}$ Shanxi dashiji, p. 59 .

${ }^{25} \mathrm{Hu}, 36$; Frank H. H. King, The Hongkong Bank in the Period of Imperialism and War: Wayfoong, the Focus of Wealth, Vol. 2 of The History of the Hongkong and Shanghai Banking Corporation (Cambridge: Cambridge University Press, 1988), p. 302.

${ }^{26}$ For the text see Mi, vol. 2, pp. 406-407. The Zongli yamen summarized the controversy in a memorial rescripted on 17 May, 1898 . See Mi, vol. 2, pp. 412-414.

${ }^{27} \mathrm{Mi}$, vol. 2, p. 407 .

${ }^{28}$ Shanxi dashi ji, p. 60.

${ }^{29} \mathrm{Mi}$, vol. 2, pp. 409, 414 .

30 MacMurray, vol. 1, pp. 700-702; Hu, p. $3^{6 .}$ 
It should come as no surprise that these rich coal fields were the ones explored and first publicized by Baron Richthofen. A second agreement with the Pekin Syndicate, allowing a short rail line to be built in northern Henan and southern Shanxi that would allow shipment of Shanxi coal to rail and water junctions, was also signed in $1898 .{ }^{31} \mathrm{With}$ these agreements in hand the syndicate soon had subscribed capital of $£_{1,520,000}$, and set to work. ${ }^{32}$ In another development, a rail line between Zhengding in Zhili and Taiyuan, Shanxi's capital, that would run through a high-quality anthracite coal region in Pingding was also specified in an agreement signed with Russia in $1898 .{ }^{33}$ Engineering parties, which had been surveying Shanxi and northern Henan in 1897 , continued their work. ${ }^{34}$ In 1898 the Zhengding-Taiyuan line was surveyed ${ }^{35}$ and in 1899 J. H. G. Glass headed a Pekin Syndicate expedition sent to verify the estimates of Shanxi's coal and iron deposits, and to look for petroleum. In addition, the Glass party was charged with making rough surveys for railroad routes that would connect the mines with navigable water routes. The party traversed Shanxi from north to south and completed a favourable report by November $1899 .^{36}$

We can see, then, how in 1896 Western-inspired business goals began directly to affect Shanxi. Beginning with a call by the governor to develop Shanxi's resources in that year, in quick order Shanxi's mineral rights had been signed away and the building of railroads had been approved. Shanxi officials, well-connected extra-provincial Chinese, reform-minded officials like Li Hongzhang, and Westerners, all played a role. But these collaborators and Westerners were opposed almost immediately, first by officials in Beijing and soon by hundreds of gentrymen and merchants in Shanxi who were pleading that mining and railroad projects should be temporarily halted. Their protests, first

31 Shanxi dashiji, pp. 6o-61.

${ }^{32}$ For subscription information see King, vol. 2, 302, and Percy Horace Kent, Railway Enterprise in China: An Account of its Origin and Development (London: Edward Arnold, 1907), p. 123. See also Shanxi dashiji, p. 60.

${ }^{33}$ Hosea Ballou Morse, The International Relations of the Chinese Empire (London: Longmans, Green, 1910-1918), vol. 3, p. 97. For a text of the agreement see MacMurray, vol. 1, pp. 367-369.

${ }^{34}$ Kent, pp. $124-125$.

35 Kent, p. 170.

${ }^{36}$ See Kent, pp. 124-125. A French engineer was sent in 1897 by the RussoChinese Bank and the Comptoire d'Escompte to survey the mineral resources of Shanxi and plan a rail route. See Cheng Lin, The Chinese Railways: A Historical Survey (Shanghai: China United Press, 1935), p. 70. 
voiced in early 1898 , continued into 1899 as preparations continued. For example, the provincial treasurer, He Shu, serving as acting governor in 1899 , explained in a memorial the socio-economic context of mining in Shanxi and why these proposed developments would be detrimental. He said that Shanxi's resources were few but that coal and iron were abundant, especially in the areas affected by the Pekin Syndicate's concession. There was no advantage, he argued, in adopting Western mining techniques. He Shu's analysis and warning, written in December 1899, is worth quoting:

[Some] local people use local methods to mine and the products are used for their own daily purposes. Other uses for the mines have to do with the slack season in the agricultural year, when poor people form together into bands that seek out new mines that they mine together and the amounts gained are very small. There are also wealthy families who amass capital resources that are used to mine relatively large-scale operations, but frequently their gains don't make up for their losses.... Now the people of Shanxi (Jinmin) are talking about these railroad and mining projects and they are very anxious about it. The people in the interior of China are not the same as those who live along the Yangzi and the coast. We are at a dangerous pass and must not take this lightly. Your minister is particularly concerned about those who are agitated. ${ }^{37}$

He Shu claimed that the people were aware of, and concerned about, these projects. There is evidence from Zezhou Prefecture, one of the syndicate's concession areas in southeastern Shanxi and the first coal region explored by Richthofen in 1870 , that supports $\mathrm{He}$ Shu's contention. Agents of the Pekin Syndicate, presumably the Glass expedition, had spent time in Zezhou in 1899 and missionaries fleeing Shanxi in 1900 passed through these same villages. Village elders quieted howling mobs only after Alexander R. Saunders, a missionary associated with the China Inland Mission, persuaded them that he was a missionary, not a Pekin Syndicate agent-he was spared. ${ }^{38}$

${ }^{37}$ He Shu memorial GX25/1 1/18. See Mi Rucheng, vol. 2, pp. 417-418.

${ }^{38}$ Saunders' 18 August, 1900 letter, written while he was in the Yangzi River treaty port of Hankou, was published in The Times on 29 September, 1900. The first word of this incident was reported from Hankou on 15 August, 1900 by the missionary Griffith John. His interviews with Shanxi missionaries who had fled the province were published in the North China Herald. He wrote the following about a refugee party's experience in Zezhou Prefecture: 'Had the gentlemen been members of the Peking [sic] Syndicate their sufferings would have been worse. At Tsechou [Zezhou] one of the missionaries was taken for a member of the Syndicate. The mob laid hold of him, and would have murdered him then and there had he not been able to convince them that he was another person'. See North China Herald, 29 August, 19oo, p. $45^{\text {o. }}$ 
Beijing had known the problem in Shanxi was growing more serious in the months after He Shu's December 1899 warning. Moreover, the seriousness of the Pekin Syndicate was becoming more apparent. Within months of the completion of the Glass report a 6 March, 1900 prospectus announced the sale of more 'Shansi shares.' The prospectus stated, according to The Times, that the Pekin Syndicate had the 'sole right for 60 years to mine coal throughout 20,000 square miles in Shan-si [Shanxi] province, the richest coal-mining area in the world' ${ }^{39}$ A week later Yuxian became Shanxi's governor.

Yuxian, as had He Shu, warned Beijing about the situation in Shanxi. In a memorial dated 18 May, 1900 Yuxian argued against the projects, based on his concerns about their effect on defence and the local economy. Yuxian also emphasized the strength of elite opposition to the projects, giving the names of the lead petitioner of three petitions: one from 192 degree-holders from throughout the province, one from 28 gentrymen from Yangqu County, the head county of Taiyuan Prefecture, and one from 430 merchants from Taiyuan City, the provincial capital. He summarized their concerns, especially their anticipation that the people's livelihood (minsheng) would be adversely affected should the railroad projects be allowed to continue. Yuxian's economic concerns were directed in part toward the transportation sector in Shanxi, which employed myriad porters and carters who came from Shanxi's poorer elements. Yuxian was also unhappy with the prospect of foreign engineers coming in and marking concession areas that would be off-limits for mining by Chinese. ${ }^{40}$ Yuxian's memorial found a receptive audience in Beijing and a rescript, dated 30 May that was sent along with copies of the petitions and Yuxian's memorial to the Zongli yamen (Chinese Foreign Office) instructed the Zongli yamen to tell Western ministers that both railroad and mining projects in Shanxi must cease. ${ }^{41}$ Yuxian's memorial was rescripted the day after the British legation had asked the yamen to direct Shanxi officials to issue a document that would guarantee the safe passage of an English engineer associated with the Pekin Syndicate who was planning to enter from Henan. On 3 June, the Zongli yamen simply asked the British to postpone the trip to Shanxi, but on 6 June, after receipt of

${ }^{39}$ The Times, 3 June, 1907, p. 5; King, vol. 2, pp. 302-303.

${ }^{40}$ Yuxian memorial GX26/4/20. See Mi, vol. 2, pp. 418-419.

${ }^{41}$ Rescript GX26/5/3 to Yuxian memorial GX26/4/20. See Mi, vol. 2, p. 419. 
Yuian's memorial and the imperial rescript, the Zongli yamen directed that the work itself in Shanxi be postponed. ${ }^{42}$

At this point rights-recovery advocates appeared to have gained the upper hand. While there is little evidence that suggests an organizational basis deserving of the label 'movement,' there is evidence of significant and widespread elite opposition throughout Shanxi in general, and in central Shanxi in particular. These voices, heard in Beijing through the agency of provincial officials, sound rational, measured, and community-spirited. For some it was not necessarily economic modernization, but rather the means of accomplishing this laudable goal, that was the issue.

It would be easy at this point to break the rights-recovery narrative, since the Boxer Uprising would be the dominant feature in the months to come. But Alexander Saunder's report, when combined with a new analysis of events in Shanxi from late June 1900 to April 1901 , suggests significant continuities. From the perspective of Shanxi officials, who knew China was at war with the Allies, the province was both a strategic and tactical linchpin in the successful strategy of keeping the Qing court out of the military grasp of foreigners. Governor Yuxian, whom we have seen supporting opponents of the Pekin Syndicate, mobilized local militias, some of which saw action along with regular Chinese troops in the defence of the passes linking Shanxi with the north China plain. This policy of aggressive defence of Shanxi's borders lasted until April 1901, when Li Hongzhang finally convinced the Qing court in Xi'an to issue withdrawal orders. ${ }^{43} \mathrm{Li}$ Hongzhang, it should be recalled, had been the most senior member of the faction that had backed the May 1898 agreement with the Pekin Syndicate.

Further research may yield more clues about this particular source of violence in Shanxi in 1900, but gaps in the documentary record make this difficult. One of the most important archival sources, the relevant published 'mining archive' records of the Zongli yamen, is largely silent for the years 1899-1901. However much anti-Pekin Syndicate proclivities motivated action in Shanxi in 1900-1901, it is clear that the Li Hongzhang-brokered surrender in April 1901

${ }^{4}$ Yihetuan dang'an shiliao xubian (Continuation of archival materials on the Boxers), edited by Zhongguo diyi lishi dang'an guan bianji bu (Beijing: Zhonghua shuju, 1990), vol. 1 , pp. $593-596$.

${ }^{43}$ Roger R. Thompson, 'Military Dimensions of the "Boxer Uprising" in Shanxi, 1898-1901', in Hans van de Ven, ed., Warfare in Chinese History (Leiden: Brill Academic Publishers, 2000), pp. 288-320. 
re-opened Shanxi to Western interests and influence reminiscent of the 1898 opening that Li's protégé had engineered. After the fires had died down, the victims mourned, and the indemnities set, missionaries and engineers soon returned to Shanxi and resumed the projects that had been interrupted, often tragically, in the summer of $1900 .{ }^{44} \mathrm{In}$ many ways the language of protest remained the same as well, but not entirely. Of particular interest is the way in which old and new became intertwined and how the language of previous conflicts, seemingly unrelated to the rights-recovery movement, may have influenced the discussions of 1902-1908. Although the discourse of $1905^{-1907}$ in particular echoed language heard in Shanxi since at least 1861, when opposition to the return of Catholic missionaries was voiced, it also reflected more recent influences, especially those coming from outside the province.

Here is evidence of a provincially-defined national movement, one that expressed in provincial terms an economic nationalism. Of course the protagonists in this struggle acted on the basis of complex motivations, but it is clear that for some a broader vision of a national project of economic modernization was part of this complex. There was also broad social composition to this movement. When elite activists talked about the 'people', this was not mere abstraction. The concerns of peasant-miners and porters were being expressed by the elite and their participation was sought and sometimes won. Surely the peasant-miners climbing mountainsides in Yangquan and claiming land for a Chinese company, peasant-miners who may have glimpsed British flags being used as survey markers by Pekin Syndicate agents in Pingding in the autumn of 1905 , must have known that inaction on their part would insure the likelihood of foreign control? ${ }^{45}$ Other evidence for the broad social composition of the movement can be found in the reported refusal of Shanxi labourers to work on the Zhengding-Taiyuan line and the observation by a well-informed Westerner living in Shanxi that the agitation in 1906 was resonating with the people and that the struggle to regain Shanxi's rights could

${ }^{44}$ See Thompson, 'Military Dimensions'. For a discussion of Yuxian and the Western representation of his actions in Shanxi see Roger R. Thompson, 'Reporting the Taiyuan Massacre: Culture and Politics in the China War of 1900', in Robert Bickers and R. G. Tiedemann, eds., The Boxers, China, and the World (Lanham, Maryland: Rowman and Littlefield, 2007), pp. 65-92.

${ }^{45}$ Kuangwu dang (Archive of mining affairs), compiled by Zhongyang yanjiuyuan jindaishi yanjiusuo (Taibei: 1960), pp. $15^{22-1} 5^{25}$ (Li Qingfang petition). 
easily embroil the whole province. ${ }^{46}$ In word and deed the elite and peasants alike were simultaneously expressing local, provincial, and national concerns.

\section{The Rights-recovery Movement, 1902-19o8}

The support of anti-Pekin Syndicate proponents in Beijing that had been won just before the beginning of the Boxer Uprising may have no longer been evident, but natives in Shanxi were undeterred in their continuing struggle to protect Shanxi's coal and iron resources from the grasping hands of foreigners. By February 1903 Governor Zhao Erxun told the court that not only was he encouraging mining activities in areas outside the Pekin Syndicate concession, but also that a company (Feng Jin kuangwu zong gongsi) headed by the wealthy Shanxi banker Qu Benqiao (Qi County, Taiyuan Prefecture) had been established to begin mining operations. ${ }^{47}$ Qu's name would re-appear in succeeding years, most notably with fund-raising that finally led to the return of mining rights to Shanxi.

In another indication of the continuities across 1900 we should note that in Shanghai a second edition of Baron Richthofen's Letters, $I 870-1872$ was published in 1903 . The third item in this volume, Richthofen's 1870 report on Shanxi's rich mineral resources, was available once again for Western readers. ${ }^{48}$ Much had changed in China in the 30 years since the volume was first published and this time there were many more Chinese able to read Richthofen's letters and to report on their contents to other Chinese. The West's monopoly on knowledge was growing smaller.

In 1904 efforts continued in the provincial yamen to restore some measure of control, as Governor Zhang Zengyang encouraged localities in Shanxi to form mining societies (kuangchan gonghui) that would give landowners willing to sell to the Pekin Syndicate a Chinese alternative. ${ }^{49}$ Among the better-documented of these societies is the

${ }^{46}$ See Lo Hui-min, ed., The Correspondence of G. E. Morrison (Cambridge: Cambridge University Press, 1976), vol. 1, pp. 375, 392-393.

47 Shanxi dashi ji, pp. 74-75.

${ }^{48}$ Baron Ferdinand von Richthofen, Baron Richthofen's Letters, I 870-I872, 2d. edn, (Shanghai, 1903).

${ }^{49} \mathrm{Li}$, p. 231. 
one established in Pingding; there were also ones established in Taiyuan and, in December 1905 , in Lu'an. ${ }^{50}$

The Pingding society's regulations followed those of the Taiyuan society. The goals of these societies were to prevent foreign ownership of Shanxi mines and also to amass capital in order to further develop indigenous mining in the province. The idea was that mine lands would be registered with the society and be sheltered as nominal public property (gongchan). Officials and people working together would be able to protect (baoshou) Shanxi's precious natural resources through vigilance and pooling capital. The apparent public-mindedness of the society contrasted with its anticipated foes: those Chinese who were renting or selling land to foreigners or who were acting as proxies. In such cases the regulations stated that the contracts should be cancelled and the land handed over to officials. While the people responsible for alienating Shanxi's resources were to be severely punished, this recognition of conflicts within Shanxi society was balanced by its stated positive goals: to unite the people's feelings and protect their resources. ${ }^{51}$

The actual carrying out of this mission appears to have been delegated to companies formed under the society's auspices. For example in Yangquan, an important mining region near the ShanxiZhili border in Pingding, grass-roots organizational work was carried out by the Guben Company (Guben gongsi), so named to highlight the twin functions of the company: to calm the people and to raise capital so that Shanxi people could carry out mining activities on their own. Two miners recalled these efforts, which were reportedly led by gentrymerchants who directed bands of miner-peasants from specific villages to stake out territory by carving the characters for 'guben' on desired mountain tops. This popular mobilization, under the guidance of the local elite and the provincial government, placed Shanxi yet again on the path towards confrontation with the West and the Pekin Syndicate. Yangquan will be used to illustrate the deepening of this conflict, but similar companies were also formed in Shouyang to the west, Jincheng (Zezhou) in the southeast, and elsewhere in Pingding Department. ${ }^{52}$

These localized efforts could become part of a broader organizational reach when well-connected and regionally-oriented

${ }^{50}$ Xue Yi, Yingguo Fu Gongsi zai Zhongguo (England's Pekin Syndicate in China) (Wuhan: Wuhan daxue chubanshe, 1992), p. 75 .

${ }^{51} \mathrm{Li}$, p. $25^{2}$.

${ }^{52} \mathrm{Li}$, pp. 231, 252; Hu, p. $4^{\mathrm{O}}$. 
companies stepped in. For example, the Yangquan villages that contributed to the efforts of the Guben Company were re-organized under the auspices of the Shanxi Tongji Kuangwu Company (Tongji kuangwu gongsi), established in February, 1905. Headquartered in Taiyuan, the company had branches in places like Pingding and Zezhou. This company encouraged the prospecting and buying of mine lands in Shanxi that had already been underway. The prejudice against foreigners remained, for only Chinese could be shareholders. But there was increasing openness to extra-provincials. For example, the extra-provincial financing of the claims-staking efforts undertaken in Yangquan's villages by the Tongji Kuangwu Company in 1905 was unproblematic. At the same time the Tongji Kuangwu Company was restricting employment opportunities to Shanxi natives. ${ }^{53}$ (But we can also infer an openness to extra-provincial contributions in a name-list of one of the 1905 student petitions, to be discussed below, that gives extra-provincial origins for at least five percent of the signatories. ${ }^{54}$ )

Pingding's Yangquan area illustrates the ambitions of both provincial and local elites and the scale of their efforts. Thirty-three villages were mobilized to stake out claims to mining areas. With 20,00o taels provided by Yuan Shikai, along with Zhili and Shanghai merchants, and an additional 10,ooo taels raised in Shanxi, the Tongji Kuangwu Company soon laid claim to about 100 square miles of mining areas in Pingding in early $1905 .{ }^{55}$ Almost certainly one of the gentry-merchants in Pingding organizing these efforts was one Song Ruyang, who came to the attention of Pekin Syndicate engineers dispatched to the area in early 1905. Although we know that Song was not alone in this well-organized undertaking, it was his village and his mine-staking that was reported to George Jamieson, the Pekin Syndicate's agent in Beijing, and to the Chinese metropolitan authorities. $^{56}$

A crisis that had been simmering heated up in July 1905 as work on the Zhengding-Taiyuan railroad reached Yangquan (Pingding department), the most troubled mining area, and a place that was destined to be a major stop on the new line. A petition drafted by a Pingding gentryman in the autumn of 1905 summarized recent events and glossed over local issues in a way worthy of close scrutiny.

\footnotetext{
${ }^{53} \mathrm{Li}$, pp. 232-233.

${ }^{54}$ Kuangwu dang, pp. 1493-1 505.

${ }^{55} \mathrm{Li}$, p. 233.

${ }^{56} \mathrm{Li}$, pp. $235^{-23} 6$.
} 
Cao Shutian, the lead petitioner of the joint petition, wrote that the original agreement between the Pekin Syndicate and the Shanxi Commercial Affairs Bureau, the agreement brokered by Liu E that was re-written along lines favoured by authorities in Beijing, had given the syndicate the responsibility to carry out, on the bureau's behalf, mining enterprises in areas where mines were closed and no longer worked or in areas where mines could not be worked with familiar techniques. But, as Cao continued:

This fall a Pekin Syndicate person, who had only a guarantee of a safe passage to enter the district, suddenly began posting flags and drawing up engineering maps. If a mine wasn't open then it couldn't be worked by [Shanxi persons] in the future.... If a mine was already being worked, then orders were given to stop. This is clearly an attempt to encroach upon the people's property (minchan). These actions, which astonished the people and disturbed peace and order, disregard the stipulations in the joint agreement and are self-serving and coercive. The people are terrified and their criticisms are mounting; it is very difficult to anticipate whether or not they might suddenly rise up. ${ }^{57}$

Among the issues that infuriated Cao and his fellow petitioners was the demand made by George Jamieson that the syndicate had virtual monopoly rights in concession areas. Although the syndicate did not have the right to expropriate native mines-it was allowed to purchase or lease fields only when owners were willing-it insisted that new mining operations could not be started by the Chinese in these areas. There were disputes over the interpretation of key clauses in the 1898 agreement. For example, the distinction between ongoing and new mining developments was shown to be problematic by Chinese officials, who explained that traditional mining was often done intermittently during the course of the agricultural season so that unworked mines were not necessarily closed mines. It did not help matters that the newly-formed Chinese mining companies in Shanxi were exploiting these ambiguities as the rail line drew closer to the coal fields. ${ }^{58}$

At the same time that these new rhetorical stances were being developed and influencing most participants, there is evidence of continuities in the methods used by older participants in the movement. The petitioning of officials by the elite in 1898-1900 (petitions that would be forwarded to Beijing) was also done after

\footnotetext{
${ }^{57} \mathrm{Li}$, p. 247.

${ }^{58} \mathrm{Hu}$, p. 4 o.
} 
1900. But this familiar tactic took an interesting twist in 1905 when a number of degree-holders, mostly shengyuan, comprised just half of the 407 signatories from Taiyuan's new-style schools. ${ }^{59}$ Here is a good example of the blurring of lines, in practice, between labels like 'traditional degree-holders' and 'modern students in new-style schools'. Among the 407 signatories were 52 normal school students, 25 of whom were commoners. ${ }^{60}$ This blurring of boundaries came earlier to Shanxi than most other places in China because of the temporary ban on civil service examinations in almost two dozen Shanxi towns and cities, including Taiyuan and Datong, imposed by the Boxer Protocol of 1901. ${ }^{61}$ It may well have been true in Shanxi that the new-style schools established in the province brought together degree-holders and commoners in ways that conferred prestige to the institutions while at the same time providing the opportunity for rapid upward social mobility to commoners who were now on a relatively equal footing with their degree-holding classmates.

The indirect role of the provincial government, when combined with the clear interest on the part of the Shanxi elite, including Shanxi natives who were officials in Beijing, meant the potential for well-organized protest was great. Petitions like Cao's were written by various groups to different levels of the government, a familiar tactic used by the elite in Shanxi. For example, 343 petitioners, led by Hanlin scholars and other degree-holders, petitioned the governor in the autumn of 1905 . They claimed to be struggling for their province's commercial advantage and to have united all the citizens (guomin) in Shanxi in this struggle to preserve Shanxi's sovereignty (zhuquan). ${ }^{62}$ (In a telling locution, translated here literally, they referred to all Shanxi's people as 'Shanxi all-province citizens' [Shanxi quansheng guomin]). ${ }^{63}$ The spirit of Cao and his fellow petitioners was echoed by the 1,014 students from Shanxi's growing network of new-style schools in Taiyuan who expressed similar sentiments. ${ }^{64}$ The students cried out in their joint petition: 'If Shanxi's coal is lost, then Shanxi is lost'. ${ }^{65}$ This petition also includes evidence of how Richthofen's 1870 statement, now commonplace among Westerners, also informed

\footnotetext{
${ }^{59}$ Kuangwu dang, pp. 1493-1505.

${ }^{60}$ Kuangwu dang, pp. $15^{\mathrm{OO}-1} 5^{\mathrm{O} 2}$.

${ }^{61}$ Shanxi dashiji, p. 70.

${ }^{62} \mathrm{Li}, \mathrm{pp} .245^{-2} 4^{6}$.

${ }^{63}$ Kuangwu dang, p. 1487.

${ }^{64} \mathrm{Li}$, pp. 247-248.

${ }^{65}$ Kuangwu dang, p. 1488.
} 
the discussion of Chinese, for there appears the figure of Shanxi's supplies being sufficient for 'several thousand years' ${ }^{66}$ The anguish of Li Peiren, who was a student at the normal school in Taiyuan, ${ }^{67}$ would become so great that words were not enough. Students from these Taiyuan schools also went to Pingding to make their own investigations, disrupted negotiations in Taiyuan between provincial officials and George Jamieson, arranged various strikes, and agitated for their cause in the streets of Taiyuan. ${ }^{68}$ These student protests continued to be echoed by more senior members of the elite. For example, late in 1905253 persons, led by a degree-holding returned student from Japan, petitioned the governor to end the agreement with the Pekin Syndicate. ${ }^{69}$

This is the provincial context for the arrival of emissaries from Sun Yat-sen's Revolutionary Alliance (Tongmeng hui), which had been formed in the summer of 1905 (20 August) and whose emissaries were in Shanxi by the winter. ${ }^{70}$ These revolutionaries, as well as reformminded returned students, could influence the drafting of petitions from late 1905 onwards. We know that Shanxi students attended meetings in Tokyo with students from other provinces, and together they protested about the Pekin Syndicate monopoly in Shanxi. ${ }^{71}$ But these returned students were but one more element in a very complex mobilization. Li Peiren, who would become a martyr to the cause, was a shengyuan (linsheng) who was educated at a new-style school in Shanxi and signed a 1905 protest petition before he left Shanxi. His example underscores the importance of using convenient labels like 'returned student' with care, for their activism could have provincial as well as cosmopolitan roots. Li, and many of his fellow Shanxi students in Tokyo, were contributing to, as well as witnessing, the nationalization of a provincial argument. The question in 1906 was how these patterns of protest, one indigenous and provincial, one extra-provincial and nationalist, would interact. The former pattern dates to the 1890 s

${ }^{66}$ Kwangwu dang, p. 1488. Richthofen's influence can also be seen in a petition submitted by 407 students to the Chinese Foreign Office (Waiwu bu), which states that Shanxi's coal reserves are number 1 in the world and quote Western newspapers that say Shanxi's coal could supply the world for over a thousand years. See Kwangwu dang, p. 1492; Li, pp. 248-249.

${ }^{67}$ Kuangwu dang, p. 1501.

${ }^{68}$ Xue, p. 72; Hu, p. 41.

${ }^{69}$ Kuangwu dang, pp. $15^{22-1} 5^{2} 5$.

${ }^{70}$ Shanxi dashi ji, p. 77 .

${ }^{71}$ Shanxi dashiji, p. 78 . 
and is the one, ultimately, that spelled success in Shanxi because these elite activists had access to money. The latter pattern is the nationalist one popularized by non-Shanxi activists in Tokyo whose rhetoric turned Shanxi into a symbol of imperialist victimization and who claimed Shanxi's coal for their own goals.

Unrest continued into 1906, supported from Beijing, where the Shanxi native Ma Cunren and several dozen other officials, including fellow provincials, sent a well-informed petition that reached the Chinese Foreign Office (Waiwu bu). ${ }^{72}$ Among the points made in this petition was an explanation of the problems in Pingding, caused by the Pekin Syndicate failing to abide by the terms of the 1898 agreement which specified that its operations could only be 'carried out in areas where it was welcome'. In Pingding, on the contrary, there was widespread opposition and many old and new mines were being occupied by the syndicate without permission. ${ }^{73}$

Events in 1906 took a tragic and highly-publicized turn in October, when Li Peiren, the degree-holder from Datong Prefecture in northeastern Shanxi studying in Tokyo at Hosei University, drowned himself in protest over Western provocation in Shanxi. Li was hailed a martyr and a convocation in Tokyo attracted about 1,ooo students (there were about 1 oo Shanxi students in Japan at the time). Similarlysized crowds soon formed in Shanxi. Li Peiren's suicide note would become a highly-charged symbol when it was returned to Shanxi, and became the focus of rallies held in his honour. In November, over 2,000 students gathered in Taiyuan and, during three days of meetings, they decided to return to their homes to spread the news about Shanxi's plight, to rally for opposition to the Pekin Syndicate, and to raise money; the Shanxi story was also carried in the national press. The following month a Pingding rally attracted 1 ,ooo people. ${ }^{74}$

Meanwhile, agents of the Pekin Syndicate were under pressure from shareholders to begin mining. On 24January, 1907, according to The Times:

[T] he British Government presented to China a demand for compensation on behalf of the syndicate for $£ 200$ a day from January 1 of this year for every

${ }^{72}$ For a discussion of how the provincial affinities of metropolitan officials affected policy-making in Beijing see Richard Belsky, Localities at the Center: Native Place, Space, and Power in Late Imperial Beijing (Cambridge Massachusetts: Harvard University Asia Center, 2005).

${ }^{73} \mathrm{Li}$, p. 257 ; Kuangwu dang, pp. $15^{8} 5^{-1} 5^{87}$.

74 Xue, pp. 72-75; Hu, p. 42. 
day's delay by the provincial authorities in issuing a permit for the syndicate to begin mining operations in the province. ${ }^{75}$

Following this display of government support the syndicate issued statements in English and Chinese that repeated the material included in the March 1900 prospectus and reminded readers that all Chinese mines opened since 21 May, 1898 should, technically, be closed down. As long as its monopoly rights were recognized, the syndicate would demonstrate that it was a 'true friend, bringing education, enlightenment, and prosperity to the province of Shan-si [Shanxi]' 76

While the Pekin Syndicate was working levers of power and influence in London and Beijing, and trying to present its case directly to the Chinese, the Shanxi elite refused to back down. Elite petitioning continued. On 26 March, 1907, for example, a petition by Shanxi's gentrymen was made public (xuanbu). It argued that the Pekin Syndicate's attempt to monopolize mining operations in $\mathrm{Yu}$, Pingding, Zezhou, and Lu'an was illegal and mentioned irritation at the syndicate's attempt to bar native mine operators from using modern machinery such as pumps. ${ }^{77}$ Another document from 1907, which was associated with gentrymen and merchants (shenmin) from Taiyuan and elsewhere, suggests how divisive this issue could be within Shanxi, for it was directed at Chinese who may have been willing to sell their lands, work in the new mines, or engage in trade with the syndicate. A total boycott was called for and those who did not comply were threatened with punishment, including banishment. ${ }^{78}$

The language used in both patterns of protests post-19oo are very similar, with references to country (guo), citizen (guomin), and sovereignty (zhuquan) to name a few of the more frequent and familiar terms. It is clear that all three terms are being used primarily in terms of provincial interests and it would be misleading to argue that by 1907 all rights-recovery activists had somehow subordinated the provincial to the national. But at the same time it is difficult to gloss over their statements as arguments for provincial prerogatives at the expense of the nation. They are arguing simultaneously for province and nation, confident that protecting Shanxi's economic self-interest would ultimately redound to the benefit of China.

75 The Times, 3 June, 1907, p. 5 . See also Lee, p. 70.

76 The Times, 3June, 1907 , p. 5 .

${ }^{77} \mathrm{Li}$, p. $25^{6 .}$

${ }^{78} \mathrm{Li}$, p. 257. 
The petitioning Shanxi elite won permission from Shanxi governor Enshou to establish yet another mining company, this one known colloquially as the 'Bao Jin', or Protect Shanxi, Company. After provincial permission was received, a Shanxi native in Beijing petitioned the Ministry of Agriculture, Commerce, and Industry in the spring of 1907 and successfully registered the company. None other than Shanxi banker Qu Benqiao, whose prototypical mining company was highlighted by Zhao Erxun in February 1903, was selected to head this 'new' company, with operational headquarters in Yangquan, branches in Jincheng, Datong, and Shouyang, and sales offices in Tianjin, Beijing, Baoding, and Shijiazhuang. The Shanxi Merchant All-Province Protect-Shanxi Mining Company, Ltd (Shanxi shangban quansheng BaoJin kuangwu youxian zong gongsi) built upon previous efforts that can be traced, for example, to the villages near Yangquan, for the old Tongji Kuangwu Company (and thus Guben Company) was subsumed under this new enterprise and would become Shanxi's first Chinese-owned large modern-style mining company. ${ }^{79}$

While the student-led publicity campaigns were propaganda successes-one 3 November, 1907 rally in Taiyuan attracted 10,000 people and smaller, but still popular, meetings held in Pingding in October sought to pressure people to cease selling land to the syndicate (even the Shanxi University graduates who had been sent to England to study railroad and mining engineering in spring 1907 added their protests to the chorus)-it was the Protect-Shanxi Company that attended to the hard task of capital formation. Money was raised from Shanxi's network of bankers as well as from the people at large, for there were occasional capital infusions from the land tax fund. While this effort was going on, a delegation of people from Shanxi visited Beijing, headed by the Judicial Commissioner (ancha shi), Ding Baoquan, ${ }^{80}$ who had been summoned to Beijing by an imperial edict of 20 September, 1907, to mediate an agreement between the Protect-Shanxi Company and the Pekin Syndicate. ${ }^{81}$ Their efforts paved the way for the beginning of negotiations in December 1907 between provincial officials and the Pekin Syndicate. It is clear the syndicate appreciated the complexity and the volatility of the

${ }^{79}$ Shanxi dashi ji, p. 81; Hu, pp. 43-46; Xue, p. 75 .

${ }^{80}$ A Judicial Commissioner, responsible for reviewing legal matters, was the thirdranking official in the provincial administration.

${ }^{81} \mathrm{Li}$, pp. 256-26o; Soothill, p. 266; Qiao Zhiqiang, 'Diguo zhuyi banli Shanxi 'jiaoan' de ezha zuixing' (Imperialism's criminal extortion in its handling of Shanxi's 'missionary cases'), Shanxi wenshi ziliao $\mathbf{2}$ (1962): 14. 
mining-rights-recovery movement in Shanxi. Moreover, it recognized, however begrudgingly, that Shanxi's coal was more than a lucrative energy resource:

$[\mathrm{T}]$ he Pekin Syndicate, after discussion, having recognized the earnest desire of the Shansi [Shanxi] people to manage their own mining affairs, has consented in the interest of public peace, and international comity, after full consideration of all the circumstances, to allow the province of Shansi [Shanxi] to redeem the aforesaid covenants for mining, working of iron and transporting of minerals, in order that the province itself may carry out the work detailed therein. ${ }^{82}$

This was the first article in the agreement reached on 20 January, 1908 that allowed the Protect-Shanxi Company to purchase the syndicate's claims on Shanxi and take over its operations. The first payment, half of a total 2.75 million taels, was to be made in February; the rest was to be paid in three annual instalments in 19o9, 1910 , and 1911. Four months shy of the ten-year anniversary of the original agreement with the Pekin Syndicate, mining rights returned to Shanxi. ${ }^{83}$

This was a signal achievement. The Pekin Syndicate itself recognized that this was both a local and global issue, and in a brief review of some of the language used in the documents just surveyed we can also glimpse a similar transformation of understanding on the part of the Chinese protagonists of this story.

\section{Echoes of the Past in the Language of Shanxi's Rights-recovery Movement}

While there are continuities across the divide of 1900 , there is a striking difference between the Beijing censors' memorials sent in 1898 and a similar group petition in 1907 . The former make personal attacks on concession negotiators Liu E and Fang Xiaojie, stress their non-Shanxi-ness, and highlight their extra-provincial connections to Anhui and Guangdong merchant wealth in Beijing and to Zhang Zhidong. These pre-190o memorials also display a concern that merchants rather than gentry and the people are controlling affairs. In 1907, however, metropolitan official Yun Yuding and Beijing-based

${ }^{82}$ MacMurray, vol. 1, p. 698.

${ }^{83} \mathrm{Hu}$, pp. $43-45$; Xue, p. 77 ; Lee, p. 7o. For a text of the agreement between the Pekin Syndicate and the Shanxi Commercial Affairs Bureau see MacMurray, vol. 1, pp. 698-700. 
officials from Shanxi attacked the specifics of the agreements and the need for renegotiation. ${ }^{84}$ Clearly there is an internationalization of a conflict previously seen in provincial and even somewhat parochial terms. The post-19oo documents also reflect changing political language. For example, the student petitions written in Shanxi and Tokyo have a different language and tone, even though there is an echo from previous petitions. The use of terms like guomin for 'citizen,' the trope about Shanxi's coal resources being number one in the world, and a more emotional style of rhetoric that can be seen in the Shanxi student petitions and Li Peiren's suicide note, are characteristics of the post-Boxer period.

It is easy also to see these connections between past and present, and province and nation, in the post-Boxer era as activists came close to using the pejorative label of hanjian or 'traitor to the Han' for anyone whose cooperation aided the Pekin Syndicate in its effort to work the concession. Some even argued that such persons should be banished. ${ }^{85}$ An extreme measure, but one that opens another line of analysis that suggests the deep-rootedness of recent Shanxi history. A similar kind of language was used by Chinese officials in Shanxi who handled conflicts between Chinese Christians and their non-believing neighbours in the years before the Boxer Uprising. Here the issue was Chinese Christian refusal, based on treaty rights extended to them on the basis of the extraterritoriality enjoyed by Western missionaries, to help pay for, or participate in, community temple festivals. The magistrate in the northeastern Shanxi city of Datong went so far as to say that Christians would have to leave the country if they continued to refuse to support temple festivals. ${ }^{86}$ Here, the connection between community and a larger political entity was very clear.

These so-called 'missionary cases' (jiaoan) were relatively scattered in pre-1900 Shanxi but the language and mindset became very widespread and deadly serious during the summer of 1900. As already argued, there is evidence that Shanxi was being mobilized for war in 1900, with regular troops and local militia groups preparing to meet the advance of Allied troops. Instructions came from Beijing that foreigners should return to their respective countries and that any Chinese Christian who defied state authority should be charged

${ }^{84}$ Kuangwu dang, pp. $15^{84-1} 5^{87}$.

${ }^{85}$ This language was used by gentrymen in Taiyuan and elsewhere in a decision made in 1907 . See Li, p. 257.

${ }^{86}$ Thompson, 'Twilight of the Gods,' p. 65 . 
with treason and could be executed. ${ }^{87}$ But Governor Yuxian took this one step further, influenced no doubt by his concern about Shanxi Christians who might aid the Allies during an invasion of Shanxi. To address that concern, which was shared by the people, Yuxian issued a proclamation that called on Chinese Christians to renounce their faith (chujiao). It seems unlikely that it was the question of faith that troubled Yuxian in 1900, but rather a secular concern of military preparedness. ${ }^{88}$ For Yuxian the goal, in the end, was national defence, with Shanxi being a strategic key point. For those Shanxi communities and individuals who had been troubled by the social and ritual implications of Chinese Christian withdrawal from accepted community practices, this proclamation was probably welcomed as long overdue. Once the China War of 1900-1901 (of which the Boxer Uprising was one element) ended, however, Westerners regained their dominance and insisted on the right of religious freedom for their followers. No Chinese Christians would be faced with such a terrible choice again in the Qing, as it became increasingly accepted that one could, in fact, be both Christian and Chinese.

How does this help us understand and analyze the language of the rights-recovery movement and its connection to the national project? In both periods we have persons who claim to speak for community putting pressure on non-conforming Chinese to renounce their connections to foreign interests. The presumption of the Datong magistrate was that jiao (religion, teaching) and China were homologous. While many in Shanxi may have agreed, this viewpoint was becoming untenable, especially after 1900 . But the template of identity created in this religious domain was secularized in the postBoxer era. Just as it became understood that more than one jiao was now acceptable in China, the exclusivity that could previously have been associated with that term came to be attached to the new and secular marker for country (guo). Loyalty to this new construct would be judged, as it was in Shanxi, by how citizens (guomin) acted locally and provincially. While all Shanxi natives were now legally guaranteed the right to choose from among several jiao, they were also now being

${ }^{87}$ See court letter of $\mathrm{GX}_{2} 6 / 6 / 10$ in Yihetuan dang'an shiliao, edited by Gugong bowuyuan Ming-Qing dang'an bu (Beijing: Zhonghua shuju, 1959), vol. 1, p. 249.

${ }^{88}$ For Yuxian's discussion of this policy see Yuxian memorial GX26/6/20 (rescript date), attachment A, Yihetuan dang'an shiliao, vol. 1, pp. 319-320. For a facsimile of a 'certificate of protection' given to a Christian in Yangqu County see E. H. Edwards, p. 110. 
enjoined to imagine, identify with, and support one country (guo). Tangible evidence of where someone stood was to be found in how they treated the blandishments of the Pekin Syndicate.

In final analysis, localism, provincialism, and the national project came together in the eyes of those rights-recovery activists who insisted that Shanxi's coal was for the use of the community, the province, and the nation on terms established by and for the people of Shanxi. Then, and only then, would it be acceptable for Baron Richthofen's dream of Shanxi coal supplying a world market to be realized. To a significant degree these demands would continue to be met throughout the Republican period associated with the rule of Yan Xishan and even into the post-1949 period, when the outward-oriented but protective provincialism of Shanxi would finally be subordinated to a different vision of the national project. ${ }^{89}$

${ }^{89}$ For the period 1911-1949 see Donald G. Gillin, Warlord: Yen Hsi-shan in Shansi Province, I9II-I949 (Princeton, New Jersey: Princeton University Press, 1967); Wright. For the post-1949 period see Elspeth Thomson, The Chinese Coal Industry: An Economic History (London: Routledge Curzon, 2003); Hu (coverage to 1979). 